\title{
Growth kinetics of diazotrophic Bacillus sphaericus UPMB10 cultured using different types and concentrations of carbon and nitrogen sources
}

\author{
Ooi, T. C., ${ }^{1}$ Ariff, A. B., ${ }^{1 *}$ Halimi, M. S. ${ }^{2}$ and Shamsuddin, Z. H. ${ }^{2}$ \\ ${ }^{1}$ Department of Bioprocess Technology, Faculty of Biotechnology and Biomolecular Sciences, Universiti Putra Malaysia. \\ 43400 UPM Serdang, Selangor, Malaysia \\ ${ }^{2}$ Department of Land Resource Management, Faculty of Agriculture, Universiti Putra Malaysia. 43400 UPM Serdang, \\ Selangor, Malaysia \\ E-mail: arbarif@biotech.upm.edu.my \\ Received 6 June 2008; received in revised form 28 July 2008; accepted 28 July 2008
}

\begin{abstract}
Growth kinetics of newly isolated diazotrophic Bacillus sphaericus UPMB10 grown in various carbon (lactate, acetate, glycerol, malate, fructose, xylose and sucrose) and nitrogen (glutamate, yeast extract, arginine, hystadine, glycine, polypeptone, tryptophan, lysine, $\mathrm{NH}_{4} \mathrm{Cl}$ and urea) sources was investigated using $2 \mathrm{~L}$ stirred tank fermenter. The highest growth was obtained in a medium containing lactate as a carbon source, which gave the highest maximum cell concentration of $2.30 \mathrm{~g} / \mathrm{L}$, which is corresponding to maximum viable cell count of $4.60 \times 10^{9} \mathrm{cfu} / \mathrm{mL}$. However, the highest cell yield (1.06 g cell/g carbon consumed) was obtained in cultivation using glycerol though slightly lower maximum viable cell count was obtained $\left(3.22 \times 10^{9} \mathrm{cfu} / \mathrm{mL}\right)$. In addition, cost for the production of live cell using glycerol was about 15 times lower than the cost using lactate. Growth performance of this bacterium when yeast extract was used as a nitrogen source was comparable to the use of pure amino acid. The medium containing $1.8 \mathrm{~g} / \mathrm{L}$ glycerol and 2 $\mathrm{g} / \mathrm{L}$ yeast extract was suggested as optimal for growth of this bacterium, which gave carbon to nitrogen ratio $(\mathrm{C} / \mathrm{N})$ of 10:1. The maximum viable cell count obtained in cultivation using optimised medium in $2 \mathrm{~L}$ stirred tank fermenter was $3.34 \times 10^{9} \mathrm{cfu} / \mathrm{mL}$ and the cells maintained its capacity for $\mathrm{N}_{2}$ fixation at $18 \mathrm{nmol} \mathrm{C}_{2} \mathrm{H}_{2} / \mathrm{h}$.mL.
\end{abstract}

Keywords: Bacillus sphaericus, diazotroph, growth kinetics, nitrogen fixing bacterium

\section{INTRODUCTION}

Nitrogen fixing bacteria have been used for centuries to improve the fertility of soils. The potential and pitfalls of exploiting nitrogen fixing bacteria in agricultural soils as substitute for inorganic fertiliser have been reviewed by Cummings et al. (2008). New $\mathrm{N}_{2}$-fixing bacilli have been isolated from roots of oil palm tree in Malaysia (Shamsuddin et al., 1999). Experiments with ${ }^{15} \mathrm{~N}$ fertilizer confirmed that the strain was capable of nitrogen fixation and identified as Bacillus sphaericus UPMB10 (Amir, 2001). This newly isolated diazotroph strain has been successfully applied on oil palm and banana crops in Malaysia.

For the preparation of biofertilizer, large-scale production of starter culture or microbial inoculants containing either single pure strain or mixed culture is essential before inoculation into suitable solid substrate for composting. The development of a commercially feasible fermentation process for large-scale production involves improvement of yield and overall productivity. Various methods of optimisation, such as experimental design, mathematical methods and kinetic models can be applied to improve the large scale cultivation process.

A wide variety of bacteria have been known to fix $\mathrm{N}_{2}$. Other than the capacity for $\mathrm{N}_{2}$ fixation, these microorganisms represent species from different taxonomic groups with totally different life-styles (FloresEncarnacion et al., 1999). Therefore, medium development for $B$. sphaericus UPMB10 should be detailed without adaptation from other $\mathrm{N}_{2}$-fixing bacteria. The main objective of the present study was to investigate the effect of different types of carbon and nitrogen sources on live cell production of $B$. sphaericus UPMB10 in $2 \mathrm{~L}$ stirred tank fermenter. Experimental data obtained were analysed using models for calculation of kinetic parameters. The kinetic information may allow better understanding of the cultivation process and may also be used for optimisation.

\section{MATERIALS AND METHODS}

\section{Microorganism and Inoculum Preparation}

B. sphaericus. UPMB10 was obtained from Department of Land Management, Universiti Putra Malaysia. A single colony of $B$. sphaericus UPMB10 was cultured in a 100 $\mathrm{mL}$ Erlenmeyer Flask containing nutrient broth (NB). The cells obtained were then resuspended in $15 \%$ glycerol $(\mathrm{v} / \mathrm{v})$ and kept as stock culture at $-80{ }^{\circ} \mathrm{C}$. For inoculum preparation, stock culture was streaked on nutrient agar (NA) slant and incubated at $30{ }^{\circ} \mathrm{C}$ overnight. A single colony was then removed from NA slant and inoculated into $100 \mathrm{~mL}$ of nutrient broth (NB) in Erlenmeyer Flasks 
(250 mL). Inoculated flasks were shaken vigorously (rotary shaker, $200 \mathrm{rev}$ per $\mathrm{min}$ ) for $10 \mathrm{~h}$ at $30^{\circ} \mathrm{C}$. Optical density of the $10 \mathrm{~h}$ culture which was approximately 0.8 (OD of 1.0 corresponds to approximately $1 \times 10^{9} \mathrm{cfu} / \mathrm{mL}$ ) was used as standard inoculum.

\section{Culture Media}

All cultivations were carried out using a basal medium consisted of $\mathrm{Na}_{2} \mathrm{HPO}_{4}, 2.8 \mathrm{~g} / \mathrm{L}, \mathrm{KH}_{2} \mathrm{PO}_{4}, 1.12 \mathrm{~g} / \mathrm{L}$, $\mathrm{CaCl}_{2} .2 \mathrm{H}_{2} \mathrm{O}, 0.01 \mathrm{~g} / \mathrm{L}, \mathrm{MgSO}_{4} .7 \mathrm{H}_{2} \mathrm{O}, 0.1 \mathrm{~g} / \mathrm{L}, \mathrm{MnCl}_{2}, 0.004$ $\mathrm{g} / \mathrm{L}, \mathrm{FeSO}_{4} .7 \mathrm{H}_{2} \mathrm{O}, 0.003 \mathrm{~g} / \mathrm{L}$, biotin, $0.003 \mathrm{~g} / \mathrm{L}$, thiamine hydrochloride, $0.03 \mathrm{~g} / \mathrm{L}$, though the type and concentration of carbon and nitrogen sources were varied according to the needs of each experiment. The effect of lactate, malate, acetate, xylose, fructose, sucrose and glycerol carbon sources on growth of $B$. sphaericus UPMB10 was studied. Sodium (Na)-acetate (5 $\mathrm{g} / \mathrm{L})$ was replaced with other carbon sources containing equal concentration of total carbon. Effect of different nitrogen sources such as glutamate, glycine, lysine, arginine, hystadine, tryptophan, yeast extract, polypeptone, ammonium chloride, and urea on growth characteristics of $B$. sphaericus UPMB10 was also studied. All nitrogen sources contained equal amount of total nitrogen as glutamate $(2 \mathrm{~g} / \mathrm{L})$. In subsequent experiment, the effect of different concentrations of selected carbon and nitrogen sources on growth kinetic of B. sphaericus UPMB10 was also investigated.

\section{Cultivation Experiments}

All cultivation experiments of $B$. sphaericus UPMB10 were carried out in a $2 \mathrm{~L}$ stirred tank fermenter (Biostat B, B. Braun, Germany) using a medium containing predetermined amounts of suitable carbon and nitrogen sources. The fermenter was equipped with $\mathrm{pH}$, temperature, dissolved oxygen tension (DOT) and foam control systems. During the cultivation, agitation speed and aeration rate was maintained at $600 \mathrm{rpm}$ (impeller tip speed $=3.1 \mathrm{~m} / \mathrm{s}$ ) and $0.5 \mathrm{vvm}$, respectively. The temperature within the fermenter vessel was controlled at $30^{\circ} \mathrm{C}$. A polarographic dissolved oxygen probe (Ingold, Switzerland) was used to measure DOT levels and the value was recorded continuously. In all cultivation experiments, shake flask containing $100 \mathrm{~mL}$ of standard was inoculated into $900 \mathrm{~mL}$ of medium in the fermenter, which gave an inoculum size of $10 \%(\mathrm{v} / \mathrm{v})$. In all cases, $\mathrm{pH}$ was uncontrolled and the initial $\mathrm{pH}$ was set at 7.0. The level of foaming was controlled by the automatic addition of antifoam A (Sigma Chemical Co., St Louis, MO).

\section{Analytical Procedures}

During the cultivation, samples were withdrawn at time intervals for analysis. The sample was centrifuged at $10,000 \mathrm{rpm}$ for $10 \mathrm{~min}$. Cells were washed and resuspended twice with $0.1 \% \mathrm{NaCl}$ for turbidity determination at $600 \mathrm{~nm}$ and was also subsequently used for measurement of dry cell weight (DCW). On the other hand, the supernatant was used for chemical analysis.
Organic acid (acetic and lactic acid) was measured using high performance liquid chromatography (HPLC) with UV detector (SPD-10A Shimadzu, Japan) at wavelength of $210 \mathrm{~nm}$

The separation of organic acid was obtained by using Biorad aminex HPX-87H cation-exchange resin column $(300 \times 7.8 \mathrm{~mm}$ I.D.) as stationary phase. The mobile phase was $7 \mathrm{mM} \mathrm{H}_{2} \mathrm{SO}_{4}$. The flow rate of mobile phase and column temperature was controlled at $1.0 \mathrm{~mL} / \mathrm{min}$ and $50{ }^{\circ} \mathrm{C}$, respectively.

Sugar in growth medium was determined using a high performance liquid chromatography (HPLC) (ConstaMetric 3000, LDC Analytical, Florida) with refractive index detector. Sample injection was performed using a sample loop valve equipped with $25 \mu$ loop. The stationary phase was a pre-packed Merck $\mathrm{NH}_{2}$ column. The mobile phase was an isocratic mixture of acetonitrile and water (80:20 $\mathrm{v} / \mathrm{v})$. Flow rate of mobile phase was set at $0.7 \mathrm{~mL} / \mathrm{min}$ and the reaction was kept at room temperature.

Total nitrogen content in culture filtrate was quantified using a micro-Kjeldahl method. A $1.0 \mathrm{~mL}$ of sample was subjected to Kjeldahl digestion in a $100 \mathrm{~mL}$ digestion flask containing concentrated sulphuric acid. The clear digest was analyzed for total $\mathrm{N}$ on a Chem Lab autoanalyser. Details of the micro-Kjeldahl and the $\mathrm{N}$ determination using an autoanalyser can be found elsewhere (Bremner and Mulvaney, 1982).

\section{Acetylene Reduction Assay}

Pre-cultures of $\mathrm{N}_{2}$-fixing bacterium were grown overnight in nitrogen free broth (NFB) supplemented with $0.05 \%$ yeast extract. Approximately $10 \mathrm{~mL}$ of culture was centrifuged and re-suspended in minimal lactate broth. The re-suspended culture was transferred into a $30 \mathrm{~mL}$ McCartney bottles sealed with rubber serum stoppers (Thomas Scientific). The McCartney bottle were then flushed with $\mathrm{O}_{2}$-free nitrogen and shaken for four hours at $30{ }^{\circ} \mathrm{C}$. The bottle was injected with $10 \%$ acetylene and incubated at $30{ }^{\circ} \mathrm{C}$. Periodically ( $15 \mathrm{~min}$ intervals) after incubation, $0.5 \mathrm{~mL}$ of gas was tested for the presence of ethylene using gas chromatography (GC) (Autosystem XL, Perkin Elmer) equipped with a flame ionisation detector and 1-m Porapak $\mathrm{N}$ column. A calibration curve was plotted for each experiment. Rate of $\mathrm{N}_{2}$ fixation was expressed as the quantity of ethylene accumulated per $h$.

\section{Mathematical Methods}

\section{Kinetic and Modeling}

The following simplified batch fermentation kinetic models for cell growth and substrate consumption based on logistic equation, which have been described elsewhere [1], were used to evaluate the growth kinetics of $B$. sphaericus UPMB10,

Cell growth:

$$
\mathrm{dX} / \mathrm{dt}=\left[\mu_{\max }\left(1-\mathrm{X} / \mathrm{X}_{\max }\right)\right.
$$


Substrate consumption:

$$
-d S / d t=\alpha(d X / d t)+\beta X
$$

Where $X$ is the cell concentration $(g / L), X_{\max }$ is the maximum cell concentration $(\mathrm{g} / \mathrm{L}), \mu_{\max }$ is maximum specific growth rate $(1 / \mathrm{h}), S$ is the substrate concentration $(\mathrm{g} / \mathrm{L}), \quad \alpha$ is growth associated constant for substrate consumption ( $\mathrm{g}$ substrate/ $\mathrm{g}$ cell), $\beta$ is the non-growth associated constant for substrate consumption ( $g$ substrate/g cell/h) and t is the fermentation time (h).

The kinetic models (equations 1 to 2) were fitted to the experimental data by non-linear regression with a Marquadt algorithm using MATLAB computer software. The model parameter values were first evaluated by solving equations 1 to 2 and then the computer program was used as a search method to minimize the sum of squares of the differences between the predicted and measured values. The predicted values were then used to simulate the profiles of cell, substrate and product concentrations during the fermentation. In order to determine whether the deviations between the experimental and calculated data are significant or notsignificant, statistical analysis (unpaired t-test) was also carried out.

Doubling time, $t_{d}(h)$ is described by equation (3),

$$
t_{d}=\ln 2 / \mu_{\max }
$$

The yield, $Y_{x / s}$, is determined by measuring the maximum cell concentration attained and total amount of substrate consumed during the fermentation,

$$
\mathrm{Y}_{\mathrm{X} / \mathrm{s}}=\left(\mathrm{X}_{\max }-\mathrm{X}_{\mathrm{i}}\right) /\left(\mathrm{S}_{\mathrm{i}}-\mathrm{S}_{\mathrm{o}}\right)
$$

Where $X_{i}$ is the initial cell concentration $(g / L), S_{i}$ is the initial substrate concentration $(\mathrm{g} / \mathrm{L})$ and $\mathrm{S}_{0}$ is the residual substrate concentration at the end of fermentation $(\mathrm{g} / \mathrm{L})$.

Overall productivity, $\mathrm{P},(\mathrm{g} / \mathrm{L} / \mathrm{h})$ was determined by measuring the total amount of biomass formed over a period of cultivation time,

$$
\mathrm{P}=\left(\mathrm{X}_{\max }-\mathrm{X}_{\mathrm{i}}\right) / \mathrm{t}
$$

\section{Statistical Analysis}

The statistical significance of the cells produced during various treatments was analysed using the SAS program (SAS, Institute Inc, 1988). Treatments were arranged according to the complete randomised design (CRD). The least significant difference (LSD) multiple comparison method was used to compare the difference between treatment means.

\section{RESULTS AND DISCUSSION}

\section{Time Course of Batch Cultivation}

Typical time course of batch cultivation of $B$. sphaericus UPMB10 using glycerol as a carbon source is shown in Figure 1, which also shows the fitness of the calculated data according to equations 1 and 2 to the experimental data. Growth of $B$. sphaericus UPMB10 was very rapid from inoculation to $10 \mathrm{~h}$ of cultivation, where lag phase was not observed. During the active growth, glycerol was rapidly consumed for growth. Dissolved oxygen tension level was concomitantly decreased with decreasing glycerol concentration in the culture, indicating that glycerol and oxygen were required for rapid growth. The culture $\mathrm{pH}$ was only slightly reduced from $\mathrm{pH} 5$ to around $\mathrm{pH} 4.5$ at the end of cultivation. From T test analysis, the deviations between the calculated and experimental data of cell growth and glycerol in the culture are not significant at a significance probability of $5 \%$. This result suggests that the proposed models based on logistic equations are sufficient to describe growth of $B$. sphaericus UPMB10 and glycerol consumption. The proposed models are also sufficient to model growth of $B$. sphaericus UPMB10 in various carbon and nitrogen sources, where the kinetic parameter values such as $\mu_{\max }$ and $X_{\max }$ were calculated through the modeling exercise.

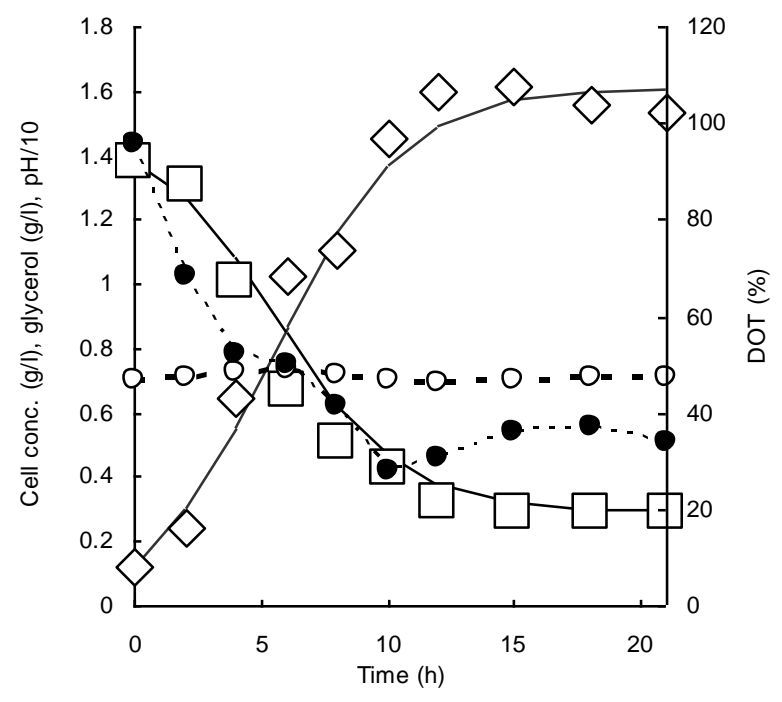

Figure 1: Time course of batch cultivation of $B$. sphaericus. UPMB10 in $2 \mathrm{~L}$ stirred tank fermenter using glycerol as a carbon source, also showing the comparison of calculated data to the experimental data. $(\bullet)$ cell concentration; ( $\boldsymbol{\square})$ glycerol concentration; $(\bullet)$ dissolved oxygen tension (\%); (O) culture $\mathrm{pH}$ ) calculated data of cell and glycerol concentrations according to the proposed models (Equations 1 and 2). 


\section{Effect of Carbon Source}

Growth of $B$. sphaericus UPMB10 was greatly influenced by the different carbon sources used in medium formulation (Table 1). The highest growth, with a final cell concentration of $2.30 \mathrm{~g} / \mathrm{L}$ with corresponding viable count of $4.60 \times 10^{9} \mathrm{cfu} / \mathrm{mL}$ was obtained when lactate was used as a carbon source. This gave the cell yield $\left(Y_{x / s}\right)$ value of $1.05 \mathrm{~g} / \mathrm{g}$, calculated as dry cell weight produced divided by the amount of carbon source consumed. The second preferred carbon source for growth of $B$. sphaericus UPMB10, which produced final cell concentration of 2.26 $\mathrm{g} / \mathrm{L}$, was acetate. Although the final cell concentration obtained in cultivation using glycerol was about 30\% lower than growth in lactate, the cell yield $\left(Y_{x / s}\right)(1.06 \mathrm{~g} / \mathrm{g})$ was slightly higher than that obtained in cultivation using lactate. In addition, $\mu_{\max }$ for growth in glycerol was significantly higher than growth in lactate and the value was comparable to growth on malate and fructose.

Growth performance of $B$. sphaericus UPMB10 on malate was relatively poor, resulting in relatively low final cell concentration. This is in contrast to a number of freeliving $\mathrm{N}_{2}$ fixers, which normally grew well on malate. Among these $\mathrm{N}_{2}$ fixers are Azospirillum brasilense SP7 (Zhulin et al., 1996), Klebsiella pneumoniae (Jack, 1998) and Bacillus spp. (Wahab and El-Sharuony, 1979). Poor growth was also observed in medium containing fructose, xylose and sucrose. In general, higher final cell concentration $\left(X_{\max }\right)$ was produced in cultivation using organic acids as compared to sugars. This could be due to the fact that $B$. sphaericus UPMB10 requires low oxygen concentration for nitrogen fixation and has evolved preference towards partially oxidized carbon source.

B. sphaericus UPMB10 was able to utilize a number of carbon sources. The highest carbon consumption was observed in cultivation using organic acid, lactate and malate, as a carbon source. During the cultivation, about $50 \%$ of the organic acid was used within $13 \mathrm{~h}$. The rate of consumption and amount of fructose, glycerol, xylose and acetate consumed during cultivation was slightly lower than for lactate and malate. The amount of sucrose consumed by $B$. sphaericus UPMB10 was very low, in which, only about $15 \%$ of the total sucrose added to the medium was consumed at the end of cultivation (24 h). This is in contrast to the growth characteristics of acidtolerant nitrogen fixing bacterium, Saccharobacter nitrocaptans, where the best growth occurred at high sucrose concentrations (10\%) (Cavalcante and Dobereiner, 1988). In addition, nitrogenous activity of Bacillus spp. was greatly enhanced with added sucrose in medium (Li et al., 1992). For acetate, malate and xylose the amount of carbon utilized did not reflect the concentration of biomass produced. This could be due to the production of by products such as exopolysaccharides or bacteriocins.

It is interesting to note that glycerol provided a better alternative carbon source for growth of $B$. sphaericus UPMB10. It was more economical to use glycerol as compared to organic acid because the cost per $\mathrm{kg}$ of cells produced was about 16 times lower as compared to lactate and 5 times lower as compared to acetate (Table $1)$.

\section{Effect of Glycerol Concentration}

Table 2 shows the effect of different concentrations of glycerol on growth of $B$. sphaericus UPMB10. Growth of this nitrogen fixing bacterium was significantly increased with increasing glycerol concentration from $0.46 \mathrm{~g} / \mathrm{L}$ to $1.38 \mathrm{~g} / \mathrm{L}$. The maximum cell concentration attained in cultivation using $1.38 \mathrm{~g} / \mathrm{L}$ glycerol was $1.51 \mathrm{~g} / \mathrm{L}$, which is corresponding to viable cell count of $3.02 \times 10^{9} \mathrm{cfu} / \mathrm{mL}$. However, the use of higher glycerol concentration up to $2.30 \mathrm{~g} / \mathrm{L}$ did not improve further growth of $B$. sphaericus UPMB10. The $X_{\max }$ and maximum viable cell count for growth in $1.38 \mathrm{~g} / \mathrm{L}$ to $2.30 \mathrm{~g} / \mathrm{L}$ glycerol were not significantly different. Cell yield $\left(\mathrm{Y}_{\mathrm{x} / \mathrm{s}}\right)$ was decreased with increasing glycerol concentration because glycerol was not only consumed as a source of carbon but also to balance the high osmotic pressure when glycerol concentration was high. Reduced $\mu_{\max }$ was observed at higher glycerol concentration, which might be due to catabolite repression by glycerol. Complete utilization of glycerol was observed when $0.46 \mathrm{~g} / \mathrm{L}$ and $0.92 \mathrm{~g} / \mathrm{L}$ glycerol was used but at higher concentration of glycerol about $0.14 \mathrm{~g} / \mathrm{L}$ residual glycerol was still remained unconsumed in the culture. The highest productivity $(0.089 \mathrm{~g} / \mathrm{L}$.h) for the cultivation of $B$. sphaericus UPMB10 was obtained at $1.38 \mathrm{~g} / \mathrm{L}$ glycerol.

\section{Effect of Nitrogen Source}

Table 3 shows growth performance of $B$. sphaericus UPMB10 in different types of amino acid and other forms of nitrogen $(\mathrm{N})$ sources. Maximum cell concentration obtained with glutamate was significantly $(P<0.05)$ higher than other $\mathrm{N}$ sources. The maximum cell concentration obtained with glutamate was $1.64 \mathrm{~g} / \mathrm{L}$. In addition, the highest $\mu_{\max }\left(0.3 \mathrm{~h}^{-1}\right)$ which is corresponding to a doubling time $\left(t_{d}\right)$ of $2.31 \mathrm{~h}$ was obtained during the cultivation in glutamate. Nitrogen $\left(\mathrm{N}_{2}\right)$ fixing bacteria such as Azospirilum lipoferum and Azospirillum amazonense have been reported to grow on glutamate as the sole nitrogen source (Hartman et al., 1988).

Yeast extract also significantly supported good growth of $B$. sphaericus UPMB10. The $\mathrm{X}_{\max }$ obtained was comparable to that obtained in cultivation using glutamate. The cell yield $\left(\mathrm{Y}_{\mathrm{x} / \mathrm{s}}\right)$ and overall productivity $(\mathrm{P})$ values for cultivation using yeast extract were higher as compared to those obtained in glutamate. It is important to note that cost of nitrogen per $\mathrm{kg}$ of cells produced from cultivation using yeast extract was five times lower than glutamate. Yeast extract has often been employed as the nitrogen source for the cultivation of $\mathrm{N}_{2}$-fixing Bacillus spp. (Wahab and El-Sharouny, 1979; Li et al., 1992), Azotobacter diazotrophicus (Bagwell, 1998) and Azospirillum (Bagwell, 1998). Yeast extract was also required to enhance nitrogeneous activity of Bacillus sp., though thiamine and biotin have more significant effect (Li et al., 1992). 
Mal. J. Microbiol. Vol 4(2) 2008, pp. 15- 25

Inorganic nitrogen source was not as good as organic nitrogen for growth of $B$. sphaericus UPMB10. It is interesting to note that ammonium chloride $\left(\mathrm{NH}_{4} \mathrm{Cl}\right)$ contributed to a higher maximum cell concentration $(0.86$ $\mathrm{g} / \mathrm{L})$ as compared to cultivation using urea $(0.28 \mathrm{~g} / \mathrm{L})$. However, both ammonium chloride and urea were only marginally utilized by $B$. sphaericus UPMB10. 
Mal. J. Microbiol. Vol 4(2) 2008, pp. 15- 25

Table 1: Effect of different carbon sources on growth characteristics of $B$. sphaericus UPMB10

\begin{tabular}{|c|c|c|c|c|c|c|c|c|}
\hline Carbon source & $\begin{array}{l}\text { Maximum cell } \\
\text { concentration, } \\
X_{\max }(g / L)\end{array}$ & $\begin{array}{l}\text { Maximum } \\
\text { Viable } \\
\text { count } \\
\text { (cfu/mL) }\end{array}$ & cell & $\mu_{\max }\left(h^{-1}\right)$ & $\begin{array}{l}\text { Carbon } \\
\text { consumed } \\
\text { during } \\
\text { cultivation (\%) }\end{array}$ & $\begin{array}{l}\text { Cell yield } \\
(\mathrm{g} \quad \text { cell } / \mathrm{g} \\
\text { carbon } \\
\text { source) }\end{array}$ & $\begin{array}{l}\text { Overall } \\
\text { Productivity } \\
\text { (g/L/h) }\end{array}$ & $\begin{array}{l}\text { Cost of } \\
\text { carbon per kg } \\
\text { of cell } \\
\text { produced } \\
\text { (USD) }\end{array}$ \\
\hline Lactate (4.26 g/L) & $2.30^{a}$ & $4.60 \times 10^{9} \mathrm{a}$ & & $0.212^{e}$ & $63.2^{a}$ & $1.05^{\mathrm{ab}}$ & $0.104^{a}$ & 48.68 \\
\hline Acetate $(3.74 \mathrm{~g} / \mathrm{L})$ & $2.26^{b}$ & $4.32 \times 10^{9 b}$ & & $0.344^{b c}$ & $54.1^{b}$ & $0.98^{\mathrm{ab}}$ & $0.102^{a}$ & 14.47 \\
\hline Glycerol (5.13 g/L) & $1.61^{\mathrm{c}}$ & $3.22 \times 10^{9} \mathrm{c}$ & & $0.344^{b c}$ & $40.6^{c}$ & $1.06^{\mathrm{a}}$ & $0.056^{b}$ & 3.00 \\
\hline Malate $(4.82 \mathrm{~g} / \mathrm{L})$ & $1.16^{d}$ & $2.32 \times 10^{9 d}$ & & $0.357^{b}$ & $64.6^{a}$ & $0.35^{d}$ & $0.026^{d}$ & 131.53 \\
\hline Fructose (4.52 g/L) & $1.05^{\mathrm{e}}$ & $2.10 \times 10^{9} \mathrm{e}$ & & $0.330^{c}$ & $37.6^{d}$ & $0.58^{c}$ & $0.036^{c}$ & 78.16 \\
\hline Xylose (4.52 g/L) & $1.05^{\mathrm{e}}$ & $2.10 \times 10^{9} \mathrm{e}$ & & $0.431^{a}$ & $29.8^{e}$ & $0.78^{b}$ & $0.036^{c}$ & $14,738.68$ \\
\hline Sucrose $(4.24 \mathrm{~g} / \mathrm{L})$ & $0.71^{f}$ & $1.42 \times 10^{9 f}$ & & $0.297^{d}$ & $15.8^{f}$ & $1.06^{\mathrm{a}}$ & $0.018^{e}$ & 10.43 \\
\hline
\end{tabular}

${ }^{a-f}$ means with the same letter are not significantly different.

$\mu_{\max }\left(\mathrm{h}^{-1}\right)$ is calculated from the modelling exercise according to equations 1 and 2 .

The amount of each carbon source used contained approximately $1.8 \mathrm{~g} / \mathrm{L}$ of total $\mathrm{C}$. 
Mal. J. Microbiol. Vol 4(2) 2008, pp. 15- 25

Table 2: Effect of different glycerol concentrations on growth characteristics of $B$. sphaericus UPMB10

\begin{tabular}{|c|c|c|c|c|c|c|}
\hline $\begin{array}{l}\text { Glycerol } \\
\text { concentration } \\
(\mathbf{g} / \mathrm{L})\end{array}$ & $X_{\max }(g / L)$ & $\begin{array}{l}\text { Viable cell } \\
\text { concentration } \\
(\mathrm{cfu} / \mathrm{mL})\end{array}$ & $\mu_{\max }(1 / h)$ & $\begin{array}{l}\text { Glycerol } \\
\text { consumed } \\
\text { during } \\
\text { cultivation (\%) }\end{array}$ & $\begin{array}{l}\text { Cell yield, } \\
\text { ( } \mathrm{g} \text { cell/g carbon } \\
\text { source) }\end{array}$ & $\begin{array}{l}\text { Overall productivity } \\
(\mathrm{g} / \mathrm{L} / \mathrm{h})\end{array}$ \\
\hline 0.46 & $1.01^{\mathrm{c}}$ & $2.02 \times 10^{9} \mathrm{c}$ & $0.37^{b}$ & $100.0^{\mathrm{a}}$ & $2.26^{a}$ & $0.058^{e}$ \\
\hline 0.92 & $1.24^{b}$ & $2.48 \times 10^{9} \mathrm{~b}$ & $0.42^{a}$ & $100.0^{a}$ & $1.39^{b}$ & $0.072^{d}$ \\
\hline 1.38 & $1.51^{\mathrm{a}}$ & $3.02 \times 10^{9} \mathrm{a}$ & $0.30^{c}$ & $89.8^{b}$ & $1.37^{b}$ & $0.089^{a}$ \\
\hline 1.82 & $1.55^{\mathrm{a}}$ & $3.10 \times 10^{9} \mathrm{a}$ & $0.27^{\mathrm{cd}}$ & $92.3^{b}$ & $0.88^{c}$ & $0.082^{b}$ \\
\hline 2.30 & $1.52^{\mathrm{a}}$ & $3.04 \times 10^{9} \mathrm{a}$ & $0.26^{d}$ & $93.9^{b}$ & $0.58^{d}$ & $0.079^{c}$ \\
\hline
\end{tabular}

${ }^{a-d}$ means with the same letter are not significantly different.

$\mu_{\max }\left(\mathrm{h}^{-1}\right)$ is calculated from the modelling exercise according to equations 1 and 2 . 
Mal. J. Microbiol. Vol 4(2) 2008, pp. 15- 25

Table 3: Effect of different nitrogen sources on growth characteristics of $B$. sphaericus UPMB10

\begin{tabular}{|c|c|c|c|c|c|c|c|c|}
\hline $\begin{array}{l}\text { Nitrogen } \\
\text { Sources }\end{array}$ & $X_{\max }(g / L)$ & $\begin{array}{l}\text { Viable cell } \\
\text { concentration } \\
(\mathrm{cfu} / \mathrm{mL})\end{array}$ & $\begin{array}{l}\mu_{\max } \\
\left(\mathrm{h}^{-1}\right)\end{array}$ & $\begin{array}{l}\text { Nitrogen utilized } \\
\text { during } \\
\text { cultivation } \\
(\%)\end{array}$ & $\begin{array}{l}\text { Cell } \\
\text { yield (g } \\
\text { cell/g N) }\end{array}$ & $\begin{array}{l}\text { Overall } \\
\text { productivity } \\
\text { (g/L/h) }\end{array}$ & $\begin{array}{l}\text { Cost } \\
\text { nitrogen } \\
\text { kg of } \\
\text { produced } \\
\text { (USD) }\end{array}$ & $\begin{array}{r}\text { of } \\
\text { per } \\
\text { cell }\end{array}$ \\
\hline Glutamate $(2.10 \mathrm{~g} / \mathrm{L})$ & $1.64^{\mathrm{a}}$ & $3.28 \times 10^{9} \mathrm{a}$ & $0.30^{\mathrm{a}}$ & $75.5^{a}$ & $1.03^{i}$ & $0.074^{c}$ & 85.58 & \\
\hline Yeast extract $(1.30 \mathrm{~g} / \mathrm{L})$ & $1.62^{b}$ & $3.24 \times 10^{9} \mathrm{~b}$ & $0.29^{a}$ & $34.8^{c}$ & $3.61^{\mathrm{e}}$ & $0.087^{b}$ & 17.29 & \\
\hline Arginine $(0.60 \mathrm{~g} / \mathrm{L})$ & $1.46^{c}$ & $2.92 \times 10^{9} \mathrm{c}$ & $0.19^{e}$ & $62.7^{b}$ & $3.89^{h}$ & $0.065^{a}$ & 97.77 & \\
\hline Hystadine $(0.75 \mathrm{~g} / \mathrm{L}$ & $1.46^{c}$ & $2.92 \times 10^{9} \mathrm{c}$ & $0.10^{c}$ & $24.2^{b}$ & $7.98^{d}$ & $0.086^{d}$ & 38.22 & \\
\hline Glycine $(1.1 \mathrm{~g} / \mathrm{L})$ & $1.38^{d}$ & $2.76 \times 10^{9} \mathrm{~d}$ & $0.11^{\mathrm{e}}$ & $63.7^{\mathrm{e}}$ & $1.99^{a}$ & $0.093^{b}$ & 27.28 & \\
\hline Polypeptone (1.45 g/L) & $1.21^{\mathrm{e}}$ & $2.42 \times 10^{9} \mathrm{e}$ & $0.12^{d}$ & $30.1^{d}$ & $2.80^{f}$ & $0.062^{d}$ & 34.92 & \\
\hline Tryptophan (1.60 g/L) & $1.06^{f}$ & $2.12 \times 10^{9 f}$ & $0.23^{d}$ & $30.8^{d}$ & $21.3^{h}$ & $0.042^{f}$ & 5.73 & \\
\hline Lysine $(0.68 \mathrm{~g} / \mathrm{L})$ & $1.03^{f}$ & $2.06 \times 10^{9 f}$ & $0.18^{b}$ & $62.5^{b}$ & $2.42^{g}$ & $0.055^{\mathrm{e}}$ & 44.17 & \\
\hline $\mathrm{NH}_{4} \mathrm{Cl}(0.75 \mathrm{~g} / \mathrm{L})$ & $0.86^{g}$ & $1.72 \times 10^{9} \mathrm{~g}$ & $0.12^{f}$ & $18.8^{f}$ & $6.13^{b}$ & $0.035^{\mathrm{g}}$ & 2.35 & \\
\hline Urea (0.45 g/L) & $0.28^{h}$ & $0.56 \times 10^{9 h}$ & $0.13^{g}$ & $12.8^{g}$ & $4.80^{c}$ & $0.010^{h}$ & 2.52 & \\
\hline
\end{tabular}

a-h means with the same letter are not significantly different.

$\mu_{\max }\left(\mathrm{h}^{-1}\right)$ is calculated from the modelling exercise according to equations 1 and 2 .

The amount of each nitrogen source used contained approximately $0.13 \mathrm{~g} / \mathrm{L}$ of total $\mathrm{N}$. 
Mal. J. Microbiol. Vol 4(2) 2008, pp. 15- 25

Table 4: Effect of different yeast extract concentration on growth characteristics of $B$. sphaericus UPMB10

\begin{tabular}{lllllll}
\hline $\begin{array}{l}\text { Yeast extract } \\
\begin{array}{l}\text { Concentration } \\
(\mathbf{g} / \mathbf{L})\end{array}\end{array}$ & $\begin{array}{l}\mathbf{X}_{\max } \\
(\mathbf{g} / \mathbf{L})\end{array}$ & $\begin{array}{l}\text { Viable } \\
\text { concentration } \\
(\mathbf{c f u} / \mathbf{m L})\end{array}$ & $\begin{array}{l}\mu_{\max } \\
\left(\mathbf{h}^{-1}\right)\end{array}$ & $\begin{array}{l}\text { Nitrogen } \\
\text { utilized } \\
\text { during } \\
\text { cultivation } \\
(\%)\end{array}$ & $\begin{array}{l}\text { Cell yield } \\
\text { (g cell/ } \mathbf{g ~ N} \\
\text { source) }\end{array}$ & $\begin{array}{l}\text { Overall } \\
\text { Productivity } \\
(\mathbf{g} / \mathbf{L} / \mathbf{h})\end{array}$ \\
\hline 0.5 & $0.50^{\mathrm{d}}$ & $1.00 \times 10^{9 \mathrm{~d}}$ & $0.22^{\mathrm{c}}$ & $38.5^{\mathrm{b}}$ & $2.55^{\mathrm{a}}$ & $0.022^{\mathrm{d}}$ \\
1.0 & $0.79^{\mathrm{c}}$ & $1.58 \times 10^{\mathrm{c}}$ & $0.20^{\mathrm{c}}$ & $42.3^{\mathrm{a}}$ & $1.49^{\mathrm{c}}$ & $0.038^{\mathrm{c}}$ \\
1.5 & $1.16^{\mathrm{b}}$ & $2.32 \times 10^{9 \mathrm{~b}}$ & $0.27^{\mathrm{b}}$ & $40.5^{\mathrm{ab}}$ & $1.77^{\mathrm{b}}$ & $0.068^{\mathrm{b}}$ \\
2.0 & $1.67^{\mathrm{a}}$ & $3.34 \times 10^{\mathrm{a}}$ & $0.28^{\mathrm{b}}$ & $41.0^{\mathrm{ab}}$ & $2.51^{\mathrm{a}}$ & $0.089^{\mathrm{a}}$ \\
2.5 & $1.65^{\mathrm{a}}$ & $3.30 \times 10^{9 \mathrm{a}}$ & $0.33^{\mathrm{a}}$ & $42.8^{\mathrm{a}}$ & $1.11^{\mathrm{e}}$ & $0.087^{\mathrm{a}}$ \\
\hline
\end{tabular}

${ }^{a-d}$ means with the same letter are not significantly different.

$\mu_{\max }\left(h^{-1}\right)$ is calculated from the modelling exercise according to equations 1 and 2 . 


\section{Effect of Yeast Extract Concentration}

Growth of $B$. sphaericus UPMB10 was significantly influenced by the concentration of yeast extract in the medium (Table 4). The $X_{\max }$ was significantly increased with increasing yeast extract concentration up to $2.0 \mathrm{~g} / \mathrm{L}$. The $X_{\max }$ obtained at $2.0 \mathrm{~g} / \mathrm{L}$ yeast extract was $1.67 \mathrm{~g} / \mathrm{L}$ which is corresponding to maximum viable count of 3.34 $x 10^{9} \mathrm{cfu} / \mathrm{mL}$. Further increased in yeast extract concentration up to $2.5 \mathrm{~g} / \mathrm{L}$ did not significantly increase the cultivation performance of $B$. sphaericus UPMB10.

Significant reduction in cell yield was observed in cultivation with yeast extract concentration lower than 2.0 $\mathrm{g} / \mathrm{L}$. Maximum growth rate $\left(\mu_{\max }\right)$ of the bacterium, as calculated from modelling exercise, was increased significantly with increasing yeast extract concentration. The $\mu_{\max }$ of $0.331 \mathrm{~h}^{-1}$ which is equal to $t_{d}$ of $2.1 \mathrm{~h}$ was achieved in cultivation using $2.0 \mathrm{~g} / \mathrm{L}$ of yeast extract.

At $2.0 \mathrm{~g} / \mathrm{L}$ of yeast extract, which was optimal for good growth of $B$. sphaericus UPMB10, about $0.637 \mathrm{~g} / \mathrm{L}$ of yeast extract was utilized. At all concentrations of yeast extract investigated, complete utilization of nitrogen source was not observed. In all cases, only about $40 \%$ of yeast extract added was utilized. The possible explanation for this is due to the fact that yeast extract used in this study only consist $45 \%$ amino acid. During the cultivation, $B$. sphaericus UPMB10 may only used the amino acids for growth while other protein in yeast extract was not utilized.

\section{Cultivation Performance using Optimized Medium}

The medium consisted of $1.38 \mathrm{~g} / \mathrm{L}$ glycerol as the carbon source and $2.0 \mathrm{~g} / \mathrm{L}$ yeast extract as the nitrogen source can be suggested as optimal for the cultivation of $B$. sphaericus UPMB10. The $\mathrm{C} / \mathrm{N}$ ratio for this optimized medium is $10: 1$. The time course for the cultivation of this nitrogen fixing bacterium in $2 \mathrm{~L}$ stirred tank fermenter using this optimized medium is shown in Figure 1. The calculated data according to the kinetic models for cell growth and substrate consumption based on logistic model (Equations 1 and 2) fitted well to the experimental data, suggesting that growth is not substrate dependent. In this cultivation run, the maximum cell concentration $\left(X_{\max }\right)$ and maximum viable cell count obtained was 1.67 $\mathrm{g} / \mathrm{L}$ and $3.34 \times 10^{9} \mathrm{cfu} / \mathrm{mL}$, respectively. According to logistic model, growth is at the maximum specific growth rate $\left(\mu_{\max }\right)$, decreased with increasing growth and the $\mu_{\max }$ became zero when growth reached a stationary phase.

The cell biomass produced using this optimized medium has more or less the same $\mathrm{N}_{2}$-fixing rate (ARA) of $18 \mathrm{nmol} \mathrm{C}_{2} \mathrm{H}_{2} / \mathrm{h} / \mathrm{mL}$ than those obtained in cultivation using organic acid (acetate). It is interesting to note that both growth and nitrogenous activity of $B$. sphaericus UPM B10 occurred in aerobic condition. This is in contrast to the characteristics of aerobic Bacillus sp. reported by Li et al. (1992), where anaerobic condition was required for nitrogenous activity. Recently, nitrogenfixing Bacillus spp. have been enumerated, isolated and identified at seedling stage in rhizosphere of rice (Khan et al., 2008). However, details characteristics of these nitrogen-fixing bacteria are not reported.

\section{CONCLUSIONS}

Growth of newly isolated diazotrophic Bacillus sphaericus UPMB10 was greatly influenced by the carbon and nitrogen sources supply into the cultivation medium. The highest cell yield (1.06 g cell/g carbon consumed) was obtained in cultivation using glycerol though slightly lower maximum viable cell count was obtained $\left(3.22 \times 10^{9}\right.$ $\mathrm{cfu} / \mathrm{mL}$ ) as compared to that obtained in cultivation using lactate $\left(4.60 \times 10^{9} \mathrm{cfu} / \mathrm{mL}\right)$. The use of yeast extract as a nitrogen source for the cultivation of this bacterium gave the highest growth and the cultivation performance was comparable to cultivation using pure amino acids. The maximum viable cell count obtained in cultivation using optimised medium containing $1.8 \mathrm{~g} / \mathrm{L}$ glycerol and $2 \mathrm{~g} / \mathrm{L}$ yeast extract in $2 \mathrm{~L}$ stirred tank fermenter was $3.34 \times 10^{9}$ $\mathrm{cfu} / \mathrm{mL}$ and the cells maintained its capacity for $\mathrm{N}_{2}$ fixation at $18 \mathrm{nmol} \mathrm{C}_{2} \mathrm{H}_{2} / \mathrm{h} / \mathrm{mL}$.

\section{REFERENCES}

Amir, H.G. (2001). Nitrogen fixation and plant growth enhancement of beneficial rhizobacteria in association with oil palm seedlings. Ph.D Thesis, Universiti Putra Malaysia, Serdang, Selangor, Malaysia.

Ariff, A. B., M. Rosfarizan, Herng, L. S., Madihah, M. S. and Karim, M. I. A. (1997). Kinetics and modelling of kojic acid production by Aspergillus flavus Link in batch fermentations and resuspended mycelial system. World Journal of Microbiology and. Biotechnology. 13: 195-201.

Bagwell, C. E., Piceno, Y. M., Ashburne-Lucas, A. and Lovell, C. R. (1998). Physiological diversity of the rhizosphere diazotroph assemblages of selected salt marsh grasses. Applied and Environmental Microbiology 64: 4276-4282.

Cavalcante, V.A. and Dobereiner, J. (1988). A new acid-tolerant nitrogen-fixing bacterium associated with sugarcane. Plant and Soil. 108 : 23-32.

Cummings, S.P., Humphry, D.R., Santos, S.R., Andrews, M. and James, E.K. (2008) The potential and pitfalls of exploiting nitrogen fixing bacteria in agricultural soils as a substitute for inorganic fertiliser. Environmental Biotechnology. 2 : 1-10.

Flores-Encarnacion, M., Contreras-Zentella, M., SotoUrzua, L., Aguilar, G.R., Baca, B.E. and Escamilla, J.E. (1999). The respiratory system and diazotrophic activity of Acetobacter diazotrophicus PAL5. Journal of Bacteriology. 181: 6987-6995.

Hartmann, A. (1989). Ecophysiological aspects of growth and nitrogen fixation in Azospirillum spp. In Nitrogen fixation with non-legumes, eds. Skinner, F.A., Bodley R. M. and Fendrik, I. pp 123-154. Kluwer Academic Publishers, London. 
Jack, R., De Zamaroczy, M. and Merrick, M. (1999). The signal tranduction protein GInK is required for NifL-dependent nitrogen control of nif Gene expression in Klebsiella pneumoniae, Journal of Bacteriology. 181: 1156-1162.

Khan, Md.H.R., Mohiuddin, Md. and Rahman, M. (2008) Enumeration, isolation and identification of nitrogen-fixing bacterial strains at seedling stage in rhizosphere of rice grown in No-Calcareous grey flood plai soil of Bangladesh. Journal of the Faculty of Environmental Science and Technology, Okayama University. 13: 97-101.

Li, C.Y., Massicote, H.B. and Moore, L.V.H. (1992). Nitrogen-fixing sp. associated with Douglas-fir tuberculate ectomycorrhizae. Plant and Soil. 140: 35-40.

Shamsuddin, Z.H., Amir, H.G., Mia, M.A.B., Halimi, M.S., Zakaria, W. and Marziah, M. (1999). Symbiotic and associative $\mathrm{N}_{2}$ fixation with vegetable soybean, oil palm and bananas. In Biotechnology for sustainable utilization of biological resources in the tropics, vol. 14, eds. Yoshida T., Seki, T., Matangkasombut P., Ebora R.V., Sukara E. \& Karim M.I.A. pp 102-118. International Center for Biotechnology, Osaka University, Osaka, Japan.

Wahab M.A. and. El-Sharouny, H.M. (1979). Nitrogenfixing $B$. species from Egyptian soils: acetylene reduction and cultural conditions. Plant and Soil 51: 187-196.

Zhulin, I.B., Bespalov, V.A., Johnson, M.S. and Taylor, B.L. (1996). Oxygen taxis and proton motive force in Azospirillum brasilense. Journal of Bacteriology 178: 5199-5204. 